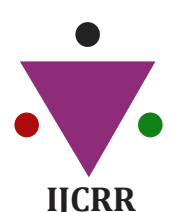

IJCRR

Section: Healthcare

Sci. Journal Impact

Factor: 6.1 (2018)

ICV: 90.90 (2018)

(c) (i) (3)

Copyright@IJCRR

\title{
Knowledge and Awareness on Role of Social Media in Managing COVID-19 Among General Population- A Questionnaire Study
}

\section{S. Barani Shankari ${ }^{1}$, Leslie Rani ${ }^{2}$, Brundha ${ }^{3}$, Jayalakshmi Somasundaram ${ }^{4}$}

\begin{abstract}
'Saveetha Dental College and Hospitals, Saveetha Institute of Medical and Technical Sciences, Saveetha University, Chennai, Tamil Nadu, India; 2Department of General Pathology, Saveetha Dental College and Hospitals, Saveetha Institute of Medical and Technical Sciences, Saveetha University, Chennai, Tamil Nadu, India; ${ }^{3}$ Associate Professor, Department of General Pathology, Saveetha Dental College and Hospitals, Saveetha Institute of Medical and Technical Sciences, Saveetha University, Chennai, Tamil Nadu, India; ${ }^{4}$ White lab - Material Research Centre, Saveetha Dental College and Hospitals, Saveetha Institute of Medical and Technical Sciences, Saveetha University, Chennai, Tamil Nadu, India.
\end{abstract}

\section{ABSTRACT}

Background: Within weeks of the emergence of the novel coronavirus COVID-19 in China, misleading rumors and conspiracy theories about the origin circulated the globe paired with fear-mongering, racism, and mass purchase of face masks, all closely linked to the new "infomedia" ecosystems of the 21 st century marked by social media. The impact of media reporting and public sentiments may have a strong influence on the public and private sectors in making decisions on discontinuing certain services including airline services, disproportionate to the true public health need. Analyses of discussions on social media with regards to the epidemic situation geographically and over time can result in real-time maps. Such real-time maps could be used as a source of information on where to intervene with key communication campaigns.

Aim: Aim of the study is to analyze the role of social media in COVID-19.

Materials and Methods: A cross-sectional survey was initiated in Coimbatore and Chennai districts of Tamil Nadu about knowledge, awareness, and perception in the role of social media.

Results and Discussion: Nearly 100 people responded. The survey data has been collected and with the help of SPSS software, data has been analyzed and plotted as a graph.

Conclusion: At the end of the study, people were somehow aware of the current status of COVID-19 and they have gained knowledge of the control and prevention of COVID-19 through social media.

Key Words: Awareness, COVID-19, Importance, Public health need, Social media, True facts

\section{INTRODUCTION}

Social media should be harnessed to support the public health response. For example, in China during the massive community-wide quarantine it is important to use social media wisely as they provide an opportunity to communicate in quarantine, provide reassurance and practical advice in order to pre-empt rumors and panic ${ }^{1}$. Digital technologies can overcome the social distancing constraints during mass quarantine ${ }^{2}$ and provide mental health support resources and solidarity with those persons in a lock-down situation ${ }^{3}$. A well-planned analysis of global online conversations could provide an assessment of the spread and possible changes in public attitudes and behaviours ${ }^{4}$ (e.g. self-isolating, hand- washing, accessing health care), awareness about the disease and its symptoms, and the impact of important decisions taken during the outbreak (e.g. quarantine measures, development of new vaccines, internationally coordinated responses) on public perceptions and attitudes ${ }^{6}$. In a contemporary discussion on the effects of media, one researcher ${ }^{7}$ stated that in some countries, social media impacted the buying crisis, when many people tried to buy toilet paper and other items because of the spreading fear of COVID-19 on social media ${ }^{8}$ According to the newspaper the, social media is responsible for much of the panic surrounding COVID-19, ${ }^{9}$ internationally leading to a situation where social media companies tried to eradicate posts about COVID-19 from their platforms..$^{10}$

\section{Corresponding Author:}

Dr. Leslie Rani, Department of General Pathology, Saveetha Dental College and Hospitals, Saveetha Institute of Medical and Technical Sciences, Saveetha University, Chennai,Tamil Nadu, India; Phone: 9360293308; Email: generalpath2015@gmail.com

ISSN: 2231-2196 (Print)

Received: 18.07 .2020
ISSN: 0975-5241 (Online)

Revised: 27.08 .2020
Accepted: 24.09 .2020
Published: 20.10 .2020 
Even before the detection of the first case of COVID-19 in India, pandemic panic hit India, which led to stock out of masks and sanitizers from the market ${ }^{11}$. Further, fake news about the transmission of the virus through petting animals, eating non-veg, etc created a panic among the public ${ }^{12}$. Unfortunately, logos and website links of national and international health agencies, news channels, and leading newspapers are being misused in such fake news ${ }^{13}$.

According to a study, in just 24 hours, there were 19 million mentions of COVID-19 across social media and news sites worldwide ${ }^{14}$. WHO claimed that social media companies were fueling misinformation on COVID-19 worldwide, some social media companies tried to remove false information from their platforms ${ }^{15}$. In India, the government has asked top social media companies like Facebook, YouTube, TikTok, ShareChat, and Twitter to stop publishing misinformation, as it misleads and creates panic among people ${ }^{16}$. In addition, it is noted that publishing inaccurate information on social media networks about the spread of diseases will have a negative impact on public health and people's mental health ${ }^{17}$. New media has become an important source of health information and a platform for discussing personal experiences, opinions, and concerns regarding health, illnesses, and treatment ${ }^{18}$. COVID-19 is a viral disease causing respiratory infections. The mode of entry to humans is through eyes, ears, nose, and mouth.

Previous work in this area includes the EBODAC project (Ebola vaccine Deployment, Acceptance, and Compliance initiative) in $2014{ }^{19}$. This included the development of country-level communication and engagement strategies to deal with problems that arose around quarantine measure ${ }^{20}$. Prior to the outbreak of COVID-19, people already relied on social media to gather information and news. Since the outbreak in December $2019^{21}$, people in many countries have relied on social media to obtain information about the virus ${ }^{22}$. Internet use is strongly associated with behaviors related to health information; users write about their health on various social media platforms ${ }^{23}$. According to Kemp there were 29.82 million internet users and 21 million social media users in Iraq in January $2020^{24}$.

Media plays a major role in creating awareness of cancers and uterine tumors ${ }^{25} 26$. Previous studies used the internet to collect data related to diseases and widely used preventive measures such as the frequency of handwashing, hand sanitizer, and antiseptic topics ${ }^{27}$. The WHO pronounced that they are presently battling a universal plague as well as a web-based media infodemic, with some media guaranteeing that the coronavirus is the principal genuine web-based media infodemic on the grounds that it has quickened data and deception worldwide and is filling frenzy and dread among people

The aim of the study is to analyze the role of social media in conveying the truth and facts of the status of COVID-19 to the general public or it misleads and panics the current situation.

\section{MATERIALS AND METHODS}

A cross-sectional survey online-based on a questionnaire was conducted among the general public residing in Coimbatore and Chennai districts of Tamil Nadu between April to May 2020. A set of 15 questions were circulated among the public based on knowledge, awareness, perception, and role of social media. A structured questionnaire was prepared by using Google forms (https://docs.google.com/forms/d/e/1F AIpQLSdiTe39xniZcC6zYjHjlKVfGK1zeP5ZTgpvp6j1Gyb$\mathrm{kc} 8 \mathrm{qPWg}$ /viewform) and it was validated with subject experts. Nearly 100 people responded to the survey. The people who use gadgets were included in the study. The people who are not interested and people who don't use mobile phones or WhatsApp were excluded. The sampling method used is simple random sampling. The data has been collected with the help of SPSS software and analyzed. The statistical tests used are descriptive analysis and mean variable. The results are plotted as a pie chart.

\section{RESULT AND DISCUSSION}

This survey has been conducted to assess the awareness level about the negative and positive roles of social media in the pandemic condition of COVID-19. This study was conducted to the people of the age group 16 to 35 .

Figure 1 represents the different media that are used by the people. $56.9 \%$ of people use all of the social media like Instagram, WhatsApp, and Facebook. 5.9\% of the respondents use Instagram; $8.8 \%$ of the respondents use WhatsApp; $6.9 \%$ of the respondents use Facebook; $6.9 \%$ of the respondents use newspaper; $9.8 \%$ of the respondents use Google.

In the year 1918, flu pandemic critical information regarding the virus was primarily shared via postal workers, boy scouts, and teachers ${ }^{28}$. In the current scenario due to development in technology news can be shared and conveyed through different portals.

Figure 2 states that out of the 100 respondents, $25.5 \%$ of the respondents say that it conveys only the true facts; $49 \%$ of the respondents say that it does not convey the true facts; and $25.5 \%$ of the respondents say that it sometimes may convey true facts.

An article says that social media does not always convey the true facts. With primary motives of influencing opinions and earning money; the wide impact of false information makes it one of the modern dangers to society, according to the World Economic Forum ${ }^{29}$. 
Figure 3 states that $24.5 \%$ of the respondents felt that social media panic the public by describing the death rates. $50 \%$ of the respondents felt that social media does not panic the public by describing the death rates; and $25.5 \%$ of the respondents felt that social media may panic the public by describing the death rates ${ }^{30}$. In similar to this study, an article says that social media panicked the public by describing the death rates during the outbreak of SARS In $2002^{31}$.

Figure 4 states that $52 \%$ of the respondents say that social media provides all the information placed by the government during lockdown; $48 \%$ of the respondents say that social media does not provide all the information placed by the government during the lockdown. There is another supporting article stating that social media provides some necessary information to the people during the pandemic - swine flu $2009^{32}$.

Figure 5 states that $52 \%$ of the respondents say that social media may give information about the status update of COVID-19 in other countries. $25.5 \%$ of the respondents say that social media does not give information about the status update of COVID-19 in other countries. $18.6 \%$ of the respondents say that social media gives information about the status updates of COVID-19 in other countries and 7.9\% of the respondents say that social media never gives information about the status update of COVID-19 in other countries. An article says that there were no social media during the pandemic - polio in 1952 and gives no information about the status update of polio in other countries too ${ }^{33,34}$.

Figure 6 states that $\mathrm{X}$-axis represents the age and the Y-axis represents the true facts conveyed by social media. In the $15-20$ age group, $10.78 \%$ says Yes (green), $5.88 \%$ says No (red), $11.76 \%$ says maybe (blue). In age group of 20-30 years $5.88 \%$ says Yes (green), $14.71 \%$ says No (red), $3.92 \%$ says maybe (blue). In the age group of $30-40$ years $7.84 \%$ says Yes (green), $26.47 \%$ says No (red), $9.80 \%$ say maybe (blue). In the age group of 40 years and above 0.96 says Yes (green), 1.96 says No (red).

Figure 7 states that $\mathrm{X}$-axis represents the age and the $\mathrm{Y}$-axis represents the opinion of people about the death rates. In the $15-20$ age group $11.75 \%$ says Yes (green), $4.90 \%$ says No (red), $11.76 \%$ says maybe (blue). In age group of $20-30$ years, $5.88 \%$ says yes (green), $15.69 \%$ says No (red), $2.94 \%$ says maybe (blue). In the age group of $30-40$ years $6.86 \%$ says Yes (green), $26.47 \%$ says No (red), $10.78 \%$ say maybe (blue). In the age group of 40 years and above $2.94 \%$ says No (red).

Figure 8 states that the $\mathrm{X}$-axis represents the age and the $\mathrm{Y}$ axis represents the opinion of people about the information placed by the government. In the 15-20 age group, $13.73 \%$ says no (blue), $14.71 \%$ says yes (red). In the age group of 20 30 years, $11.76 \%$ says no (blue), $12.75 \%$ says yes (red). In the age group of $30-40$ years, $20.5 \%$ says no (blue), $23.53 \%$ says yes (red). In the age group of above 40 years, $1.96 \%$ says no (blue), $0.98 \%$ says yes (red).

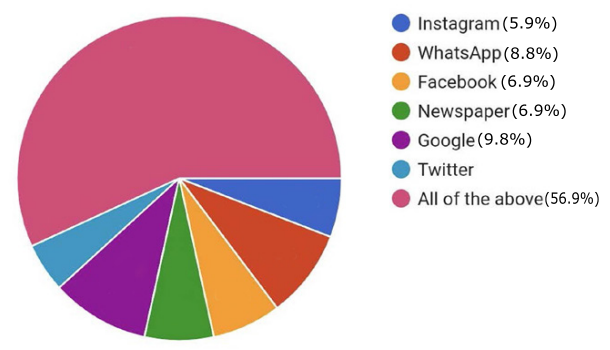

Figure 1: The pie chart showing responses to the question 'which of the following media is mostly preferred by you', where the pink represents all of the above $(56.9 \%)$, dark blue represents Instagram (5.9), red represents WhatsApp (8.8\%), orange represents Facebook (6.9\%), green represents newspaper $(6.9 \%)$, violet represents Google $(9.8 \%)$, and light blue represents twitter(4.8\%).

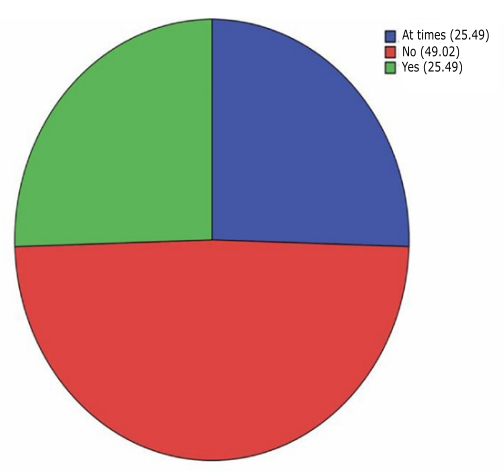

Figure 2: The pie chart showing responses to the question 'do you think social media conveys only true facts', where the red represents No (49\%), blue represents at times $(25.5 \%)$, and green represents Yes $(25.5 \%)$.

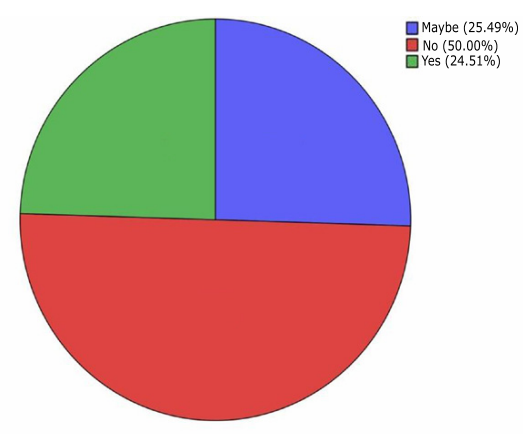

Figure 3: The pie chart showing responses to the question 'does social media panics people by describing the death rates', where the red represents No $(50 \%)$, blue represents maybe $(24.5 \%)$, and green represents Yes (25.5\%). 


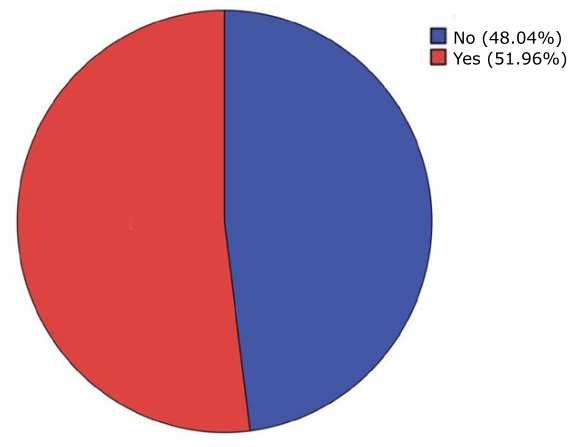

Figure 4: The pie chart showing responses to the question 'Are you aware of all the information and order placed by the government during this lockdown', where the blue represents No $(48 \%)$, and red represents Yes (52\%)

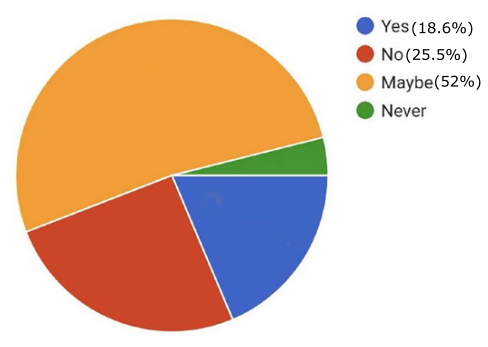

Figure 5: The pie chart showing responses to the question 'does social media gives an update of COVID-19 of other countries', where the red represents No (25.5\%), blue represents Yes $(18.6 \%)$, orange represents maybe $(52 \%)$, and green represents never (3.9\%).

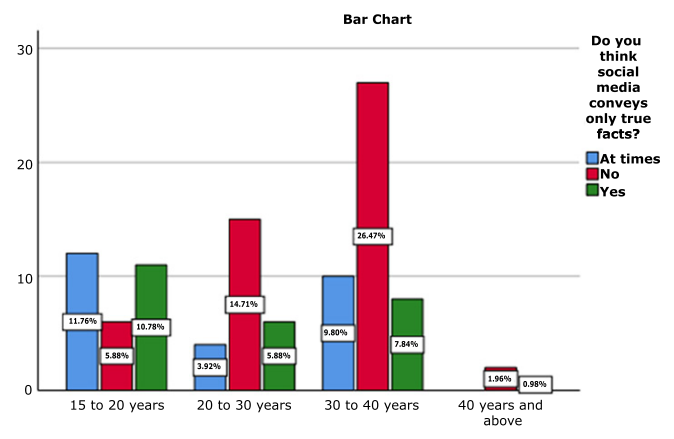

Figure 6: Bar chart representing the association between age and opinion of people about the true facts conveyed by social media. $\mathrm{X}$-axis represents the age and $\mathrm{Y}$-axis represents the number of responses. Blue color indicates at times, red color indicates No, green color indicates Yes. The majority of people $(26.47 \%)$ in the age group between 30 to 40 years are aware that social media not only conveys true facts. The Chi-square test was done to analyze the association between variables. Pearson Chi-square value is $14.274, \mathrm{p}$-value is $0.027(<0.5)$. Hence there is no statistical significance.

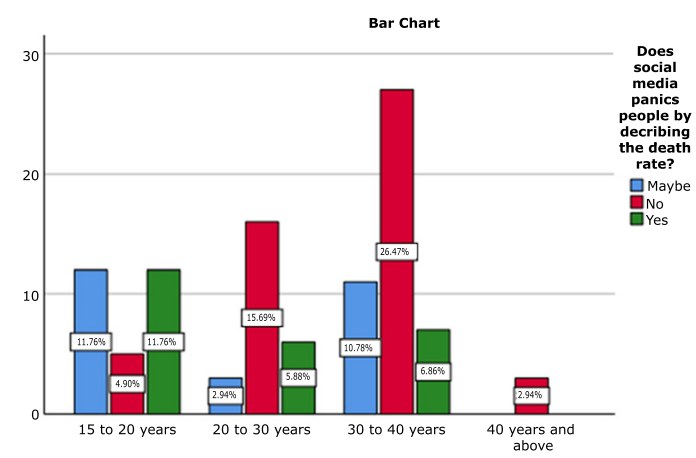

Figure 7: Bar chart representing the association between age and opinion of people about the information of death rates that panics people. $\mathrm{X}$-axis represents the age and $\mathrm{Y}$-axis represents the opinion of people about the information on death rates that panic people. Blue color indicates maybe, red color indicates no, green color indicates yes. The majority of people $(26.4 \%)$ in the age group of 30 to 40 years are against the statement that social media panics the people by describing the death rates. The Chi-square test was done to analyze the association between the variables. Pearson Chi-square value is 20.622 , p-value is $0.002(<0.05)$. Hence, it is statistically significant.

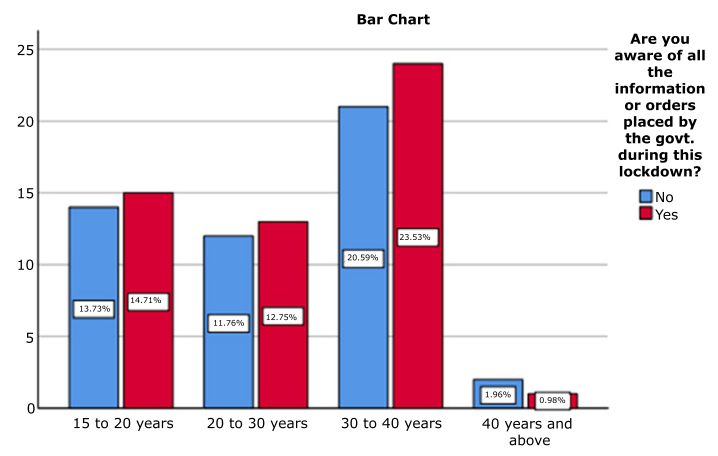

Figure 8: Bar chart representing the association between age and awareness of people about the information placed by the government. $\mathrm{X}$-axis represents the age and the $\mathrm{Y}$-axis represents the awareness of people about the information placed by the government. Blue color indicates no, red yes. People of the age group between $30-40(23.53 \%)$ years are more aware of the information given by the government. The Chi-square test was done to analyze the association between the variables. Pearson Chi-square value is $0.452, p$-value is $0.929(>0.05)$. Hence, there is no statistical significance.

The time in which the respondent completed the questionnaires may have influenced their perception level. This study is based on a small geographical area with a limited sample size where it can extend throughout the country. Also, it was conducted in a short duration period and accordingly collected responses were fewer. 


\section{CONCLUSION}

From the study, it is shown that the majority of people have gained knowledge and awareness on COVID-19, through social media. Social media is a common platform shared by all communities of people. They convey the orders and information placed by the government during quarantine and people have realized to some extent about the happenings in the country. People are advised not to randomly believe all the information. Social media should focus on the truths and facts to keep the people updated and should not panic the public by spreading fake news. People have to analyze whether the gathered information through social media is true or false by various other sources in order to get the correct information.

\section{ACKNOWLEDGMENT}

Authors acknowledge the immense help received from the scholars whose articles are cited and included in references to this manuscript. The authors are also grateful to authors / editors / publishers of all those articles, journals, and books from which the literature for this article has been reviewed and discussed.

\section{Conflict of Interest: Nil}

\section{Source of Funding: Nil}

\section{REFERENCES}

1. Larson HJ. The biggest pandemic risk? Viral misinformation. Nature. 2018 Oct;562(7727):309.

2. Mp B, Brundha MP, Nallaswamy D. Hide and seek in pathology- A research on game-based histopathology learning [Internet]. Vol. 10, International Journal of Research in Pharmaceutical Sciences. 2019. p. 1410-4. Available from: http://dx.doi. org/10.26452/ijrps.v10i2.606

3. McCauley M, Minsky S, Viswanath K. The H1N1 pandemic: media frames, stigmatization and coping. BMC Public Health. 2013 Dec 3;13:1116.

4. Wilson ME, Chen LH. Travellers give wings to novel coronavirus (2019-nCoV) [Internet]. Vol. 27, Journal of Travel Medicine. 2020. Available from: http://dx.doi.org/10.1093/jtm/taaa015

5. Brundha MP, Pathmashri VP, Sundari S. Quantitative Changes of Red Blood cells in Cancer Patients under Palliative Radiotherapy-A Retrospective Study [Internet]. Vol. 12, Research Journal of Pharmacy and Technology. 2019. p. 687. Available from: http://dx.doi.org/10.5958/0974-360x.2019.00122.7

6. King NB. Mediating Panic [Internet]. Empires of Panic. 2015. p. 181-202. Available from: http://dx.doi.org/10.5790/hongkong/9789888208449.003.0008

7. Timothy CN, Samyuktha PS, Brundha MP. Dental pulp Stem Cells in Regenerative Medicine - A Literature Review [Internet]. Vol. 12, Research Journal of Pharmacy and Technology. 2019. p. 4052. Available from: http://dx.doi.org/10.5958/0974360x.2019.00698.x
8. Prashaanthi N, Brundha MP. A Comparative Study between Popplet Notes and Conventional Notes for Learning Pathology [Internet]. Vol. 11, Research Journal of Pharmacy and Technology. 2018. p. 175. Available from: http://dx.doi.org/10.5958/0974360x.2018.00032.x

9. Kumar MDA, Ashok Kumar MD, Brundha MP. Awareness about nocturia-A questionnaire survey [Internet]. Vol. 9, Research Journal of Pharmacy and Technology. 2016. p. 1707. Available from: http://dx.doi.org/10.5958/0974-360x.2016.00344.9

10. Hannah R, Ramani P, Brundha MP, Herald. J. Sherlin, Ranjith G, Ramasubramanian A, et al. Liquid Paraffin as a Rehydrant for Air Dried Buccal Smear [Internet]. Vol. 12, Research Journal of Pharmacy and Technology. 2019. p. 1197. Available from: http:// dx.doi.org/10.5958/0974-360x.2019.00199.9

11. Depoux A, Martin S, Karafillakis E, Preet R, Wilder-Smith A, Larson $\mathrm{H}$. The pandemic of social media panic travels faster than the COVID-19 outbreak [Internet]. Vol. 27, Journal of Travel Medicine. 2020. Available from: http://dx.doi.org/10.1093/jtm/ taaa031

12. Dey S. Modeling COVID19 in India (MAR 3 - MAY 7, 2020): How flat is flat, and other hard facts [Internet]. Available from: http://dx.doi.org/10.1101/2020.05.11.20097865

13. King A. Fast news or fake news?: The advantages and the pitfalls of rapid publication through pre-print servers during a pandemic. EMBO Rep. 2020 Jun 4;21(6):e50817.

14. Preethikaa S, Brundha MP. Awareness of diabetes mellitus among general population [Internet]. Vol. 11, Research Journal of Pharmacy and Technology. 2018. p. 1825. Available from: http://dx.doi.org/10.5958/0974-360x.2018.00339.6

15. Shreya S, Brundha MP. Alteration of Haemoglobin Value in Relation to Age, Sex and Dental Diseases-A Retrospective Correlation Study [Internet]. Vol. 10, Research Journal of Pharmacy and Technology. 2017. p. 1363. Available from: http://dx.doi. org/10.5958/0974-360x.2017.00241.4

16. Kalaiselvi R, Brundha MP. Prevalence of hysterectomy in South Indian population [Internet]. Vol. 9, Research Journal of Pharmacy and Technology. 2016. p. 1941. Available from: http:// dx.doi.org/10.5958/0974-360x.2016.00398.x

17. Harsha L, Brundha MP. Prevalence of dental developmental anomalies among men and women and its psychological effect in a given population. Res J Pharm Biol Chem Sci. 2017;9(6):869.

18. Ravichandran H, Brundha MP. Awareness about personal protective equipments in hospital workers (sweepers and cleaners). International Journal of Pharmaceutical Sciences Review and Research. 2016;40(1):28-9.

19. Atlani-Duault L, Ward JK, Roy M, Morin C, Wilson A. Tracking online heroisation and blame in epidemics [Internet]. Vol. 5, The Lancet Public Health. 2020. p. e137-8. Available from: http:// dx.doi.org/10.1016/s2468-2667(20)30033-5

20. Wilder-Smith A, Freedman DO. Isolation, quarantine, social distancing and community containment: pivotal role for old-style public health measures in the novel coronavirus (2019-nCoV) outbreak. J Travel Med [Internet]. 2020 Mar 13;27(2). Available from: http://dx.doi.org/10.1093/jtm/taaa020

21. Pappot N, Taarnhøj GA, Pappot H. Telemedicine and e-Health Solutions for COVID-19: Patients' Perspective [Internet]. Telemedicine and e-Health. 2020. Available from: http://dx.doi. org/10.1089/tmj.2020.0099

22. Hernández-García I, Giménez-Júlvez T. Assessment of Health Information About COVID-19 Prevention on the Internet: Infodemiological Study [Internet]. Vol. 6, JMIR Public Health and Surveillance. 2020. p. e18717. Available from: http://dx.doi. org/10.2196/18717 
23. McGowan BS, Wasko M, Vartabedian BS, Miller RS, Freiherr DD, Abdolrasulnia M. Understanding the Factors That Influence the Adoption and Meaningful Use of Social Media by Physicians to Share Medical Information [Internet]. Vol. 14, Journal of Medical Internet Research. 2012. p. e117. Available from: http://dx.doi.org/10.2196/jmir.2138

24. Woo H, Cho Y, Shim E, Lee J-K, Lee C-G, Kim SH. Estimating Influenza Outbreaks Using Both Search Engine Query Data and Social Media Data in South Korea [Internet]. Vol. 18, Journal of Medical Internet Research. 2016. p. e177. Available from: http:// dx.doi.org/10.2196/jmir.4955

25. Balaji S, Brundha MP, Path DNB. Awareness of About Breast Cancer among Dental Surgeons. Res J Pharm Biol Chem Sci. 2016;8(8):797.

26. Shenoy PB, Brundha MP. Awareness of polycystic ovarian disease among females of age group 18-30 years. Res J Pharm Biol Chem Sci. 2016;8(8):813.

27. Sharp PA. 1918 Flu and Responsible Science [Internet]. Vol. 310, Science. 2005. p. 17-17. Available from: http://dx.doi. org/10.1126/science.310.5745.17

28. Siegel M. Swine Flu: The New Pandemic. Wiley; 2009. 84 p.

29. Social Media and Social Network Sites [Internet]. A Critical Hy- pertext Analysis of Social Media : The True Colors of Facebook. Available from: http://dx.doi.org/10.5040/9781472541857.ch001

30. P Jannathulferdioz BM. Awareness of Stye. Int J Pharm Sci Rev Res,. 40(1):30-2.

31. Kaplan AM, Haenlein M. Users of the world, unite! The challenges and opportunities of Social Media [Internet]. Vol. 53, Business Horizons. 2010. p. 59-68. Available from: http:// dx.doi.org/10.1016/j.bushor.2009.09.003

32. Shah A. The Relationship between General Population Suicide Rates and the Internet: A Cross-National Study [Internet]. Vol. 40, Suicide and Life-Threatening Behavior. 2010. p. 146-50. Available from: http://dx.doi.org/10.1521/suli.2010.40.2.146

33. Hampton M. Book Review: Brian Winston, Messages: Free Expression, Media and the West from Gutenberg to Google. London and New York: Routledge, 2005 [Internet]. Vol. 30, Media, Culture \& Society. 2008. p. 429-30. Available from: http:// dx.doi.org/10.1177/01634437080300030903

34. Brundha MP. A Comparative Study-The Role of Skin and Nerve Biopsy in Hansen's Disease. Res J Pharm Biol Chem Sci. 2015;7(10):837. 